\title{
Student Computational Logical Thinking of Block Programming Concept in Arduino Learning By S4A (Scratch for Arduino)
}

\author{
$1^{\text {st }}$ Umi Pratiwi \\ Department of Physics Education, \\ Faculty of Teacher Training and \\ Education \\ Muhammadiyah University of \\ Purworejo \\ Purworejo, Indonesia \\ umipratiwi@umpwr.ac.id
}

\author{
$2^{\text {nd }}$ Sriyono \\ Department of Physics Education, \\ Faculty of Teacher Training and \\ Education \\ Muhammadiyah University of \\ Purworejo \\ Purworejo, Indonesia
}

\author{
$3^{\text {rd }}$ R. Wakhid Akhdinirwanto \\ Department of Physics Education, \\ Faculty of Teacher Training and \\ Education \\ Muhammadiyah University of \\ Purworejo \\ Purworejo, Indonesia
}

\begin{abstract}
The purpose of this study was to determine the change in students computational logical thinking ability after the implementation of Scracth for Arduino (S4A) in block programming learning. The population in this research were all students of physics application for computer (Aplikom) course, consisted of 9 student academic year 2018, Department of Physics Education, Faculty of Teacher Training and Education, University of Muhammadiyah Purworejo. This study employed a quasi-experimental design with pretest-posttest one group design. The result of the research showed that the average of students computational logical thinking ability of block programming before implementation scratch for arduino was $69 \%$ and after implementation was $74,86 \%$. It means that student's ability of computational logical thinking increase. This is indicated by the increased ability to make conclusion or make prediction based on the correlation between cases was $17,4 \%$. It was also showed that there was an increased in compiling analysis and synthesis of several cases by $6,7 \%$.
\end{abstract}

Keywords-S4A; computational logical thinking; block programming

\section{INTRODUCTION}

The fourth industrial revolution is a change in human life patterns that focuses on data management, utilization of technological advances, ICTs, and work efficiency improvements related to human interaction. Changes in human work are supported by the progress of computing and data storage systems without any partition, space and time (Thai and Anh, 2017). Universities are educational institutions that can produce quality workforce in accordance with the demands of the industrial revolution era 4.0. Higher education is demanded to produce a workforce that is highly adaptable and has a HOT (Higher Order Thinking) mindset that is always dynamic towards changing times. Besides that, it is needed the ability to solve problems faced by hard work or the ability to think critically about the problems that exist around the environment (Penprase, 2018)
The development of information and communication technology (ICT) has a major impact on natural education, such as the fields of pure physics and physics education. Especially in the field of physics education, the development of ICTs helps students in learning to understand the concept of physics. most theoretical physics of abstract can be used as learning media tools to be real, so that it is easily understood by students. This technology facilitates education in carrying out learning such as microcontroller technology (Nethravthi dan getha, 2016)

Microcontroller technology is a complete computer system in one chip. Microcontroller is more than just a microprocessor because it already exists or contains ROM (Read-Only Memory), RAM (Read-Write Memory), several input and output ports, and several peripherals such as counter / timer, ADC (Analog to Digital converter), DAC (Digital to Analog converter) and serial communication (Santoso et al, 2013). This microcontroller can be combined with sensor work to detect and respond to several types of input from the physical environment. Specific input can be in the form of physical quantities and physical phenomena in the environment around us like light, heat, motion, humidity, pressure, or one of a large number of other environmental phenomena (Mon and Kuo, 2016).

The combination of a microcontroller with a sensor requires a mediator in the form of a programming language. The microcontroller on the market has of many types, the Arduino microcontroller is the easiest programming language. So that in learning practices often uses Arduino. Besides that it is opened source and easy to carry because it is small (Aozon, 2014). Arduino Uno is a microcontroller used in this study. Because of this ease, Arduino Uno is used in the physics learning of the Computer Application course for Physics (Aplikom) to help making physics teaching aids. Learning in this course students are invited to learn computer programming namely Arduino programming. Arduino programming is easier than other programming such as Matlab and $\mathrm{C}++$. 
Physics subjects are mostly abstract it can be used as learning media tools to be real, so it's easy to be enderstood by students. This technology facilitates education in carrying out learning such as microcontroller technology. The combination of a microcontroller with a sensor required a mediators such as programming languages that can be used as physics teaching aids. There are many obstacles in the process of learning physics, especially the aplikom's course, students do not have ability to logic procedurally. Evem many of aplikom's course participants have never studied computer programming languages, this is major obstacles in the learning process. To overcome these obstacles researchers applied S4A (Scratch for arduino) learning to determine the computational logical thinking ability in learning arduino programming languages in the aplikom course. S4A as a programming languages in the form blocks or block programming. So it is expected that with S4A learning student have the ability do develop computational logical thinking (Chong li, 2016).

There are many obstacles in the physics learning process, especially the Aplicom course, which is that students do not have the ability to practice procedurally. Even many of Aplikom's course participants have never studied computer programming languages. This is a major obstacle in the learning process. To overcome these obstacles researchers applied S4A (Scratch for Arduino) learning to determine the ability to think logically and think computationally in learning the Arduino programming language in the Aplikom course. This S4A as a software helps beginner programmers in learning Arduino programming languages. So that in the end the hope of the researchers of the students can make and be able to develop their own teaching aids based on the microcontroller especially Arduino Uno as a tool in the learning process of Physics so that it is more real.

\section{METHODS}

\section{A. Research Design}

This research is an experimental study with a quantitative research approach supported by a qualitative-description approach. This experimental research is a type of Pre experimental design research which is an experiment that is often considered an experiment that is not actually called quasi experiment. This research is a pre-experimental study with the design of Pretest-posttest one group design.

\section{B. Participant}

The population in this study consisted of all students in the 2018 course of Aplikom (computer applications for physics) as the elective course, Department of Physics Education, Teaching and Education Faculty, University Muhammadiyah of Purworejo. The number of students sampled is 9 students.

\section{Procedure}

Design patterns from one pretest-post test group were observed before the experiment and after the experiment. Preliminary tests conducted before the experiment are called pretest, and the final test after the experiment is called a posttest, while the experimental treatment or effect is carried out during learning (Arikunto, 2002. More detailed action of the researcher in the initial test is to guide students to fill out questionnaires to determine students' initial abilities about computer programming and knowledge of Arduino microcontrollers Preliminary tests to find out the initial description of the ability to think logically with the Pascal programming language After that, S4A learning is given (initial for Arduino) After everything is finished or in the last test (post test) the final test is carried out again using S4A learning (beginning for Arduino) to determine the ability to think logically in physics educating students (prospective teachers).

\section{RESULTS AND DISCUSSION}

Computational logical ability is very necessary for physics education students, especially in solving problems related to physics. This ability is closely related to the ability to think that is in the cognitive domain. Cognitive ability is the ability to think of students, knowing, solving problems which include intellectual abilities, namely remembering, connecting and combining several ideas, ideas, and methods to solve problems (Setiawan, 2008). This ability requires high reasoning which is known as the ability to think logically.

The ability to think logically is also the ability to think consistently until making conclusions. This ability is very necessary in the ability to solve physical problems related to computer programming for physics. Computational logical thinking ability has 7 (seven) indicators that are used as student assessment parameters. The ability to think logicallycomputing begins with an initial test to test how much the level of students' logical thinking skills. The initial test questions consist of 5 (five) reasoning questions with a short working time, each question is a maximum of only 5 minutes. Problem 1 s.d. question 5 has different characteristics.

Figure 1 and Figure 2 below show a percentage of 7 indicators of students' logical computing ability.

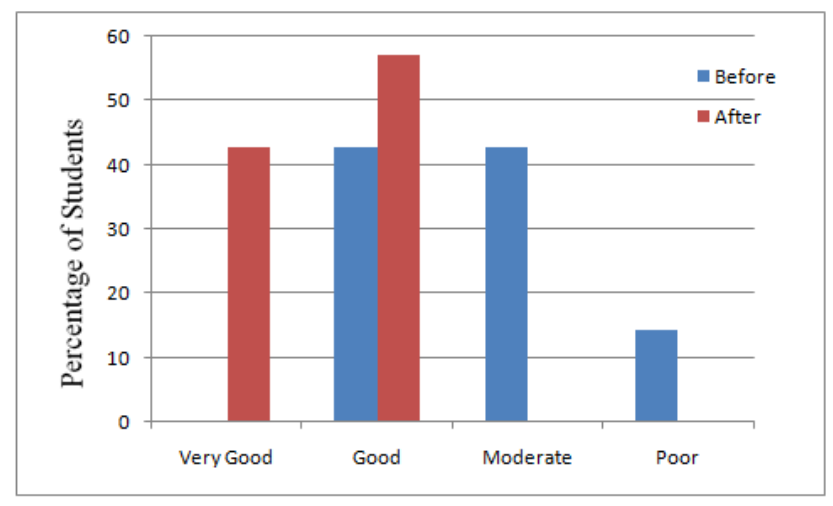

Figure 1. Graph of the logical ability of student computing in completing the project

Based on the graph analysis of students 'logical ability in completing the project above, that students' logical thinking ability before and after the S4A implementation there is a 
significant difference. Learning before the S4A application there were no students who got very good category scores, while learning after the S4A application experienced a significant increase for the very good category value. Learning before the implementation of S4A students have computational logical thinking ability on average in the categories of good $(42.86 \%)$ and moderate $(42.86 \%)$. Computational logical thinking ability has increased after learning with the application of S4A with Very good category $(42.86 \%)$ and Good category $(57.14 \%)$.

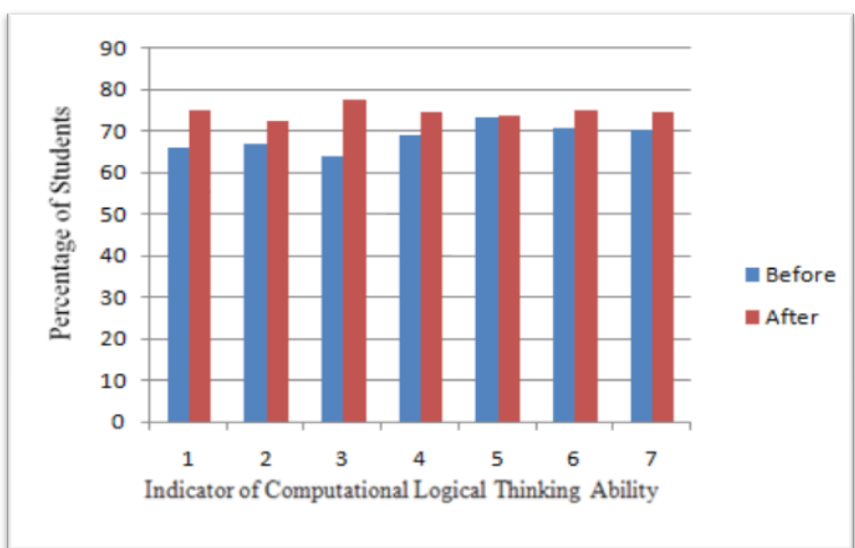

Figure 2. Value of students' logical thinking ability for 7 indicators

The picture above shows the computational logical thinking ability before and after the S4A application in completing the project which is assessed with 7 indicators. The third indicator is Make conclusions or make estimates or predictions of correlation between two variables has the biggest increase of $17.5 \%$.

This ability is the ability of students to solve problems faced by interpreting in the form of a settlement model using a microcontroller and the required components. While the 5th indicator is Analyzing hypotheses based on the similarity of the two processes, having a small increase of only $0.75 \%$.

The fifth indicator capability is the ability of students to interpret solutions with other alternative arduino programming language algorithms. This is because there is still a lack of students in getting used to making Arduino programming algorithms that will be represented in the form of block programming. While for other indicators, the increase was moderate with an average increase of $5.63 \%$.

The average difficulty faced by students is the ability to represent problems in the algorithmic language of the Arduino programming language which is then re-represented using $\mathrm{S} 4 \mathrm{~A}$ in the form of a bahaa block programming. This is because the S4A learning time is too short and is still focused on learning Arduino programming and assembling hardware components.

The results of the computational logical thinking ability assessment for 7 indicators can be seen in table 1 below.
Table 1. Value of students' logical thinking ability in completing the project

\begin{tabular}{|c|l|c|c|}
\hline No & \multicolumn{1}{|c|}{$\begin{array}{c}\text { Indicator of computational logical } \\
\text { thinking ability }\end{array}$} & Before & After \\
\hline 1 & $\begin{array}{l}\text { Make conclusions or make estimates and } \\
\text { based on appropriate proportions }\end{array}$ & 66,23 & 75,00 \\
\hline 2 & $\begin{array}{l}\text { Make conclusions or make estimates and } \\
\text { predictions of opportunities }\end{array}$ & 66,95 & 72,50 \\
\hline 3 & $\begin{array}{l}\text { Make conclusions or make estimates or } \\
\text { predictions of correlation between two } \\
\text { variables }\end{array}$ & 63,95 & 77,50 \\
\hline 4 & $\begin{array}{l}\text { Make a combination of solutions from } \\
\text { several variables }\end{array}$ & 69,23 & 74,50 \\
\hline 5 & $\begin{array}{l}\text { Analyzing hypotheses based on the } \\
\text { similarity of the two processes }\end{array}$ & 73,25 & 74,00 \\
\hline 6 & Proving the chosen solution & 70,75 & 75,00 \\
\hline 7 & $\begin{array}{l}\text { Prepare analysis and synthesis of cases. } \\
\text { Averge }\end{array}$ & $\mathbf{6 8 , 7 0}$ & $\mathbf{7 4 , 7 6}$ \\
\hline
\end{tabular}

Table 1 shows the students' logical thinking skills in the application of the Aplikom Course and Figure 2 shows significant and significant changes. An important point of computational logical thinking ability in the 5th indicator is Proving the chosen solution and the 7th is Analyzing hypotheses based on the similarity of the two processes, even though they experience a small increase. In the ability that shows the representation of the ability of students in the form of block programming language determines the final solution in solving the completion of the project. Below is a picture showing the ability on the 5th indicator.
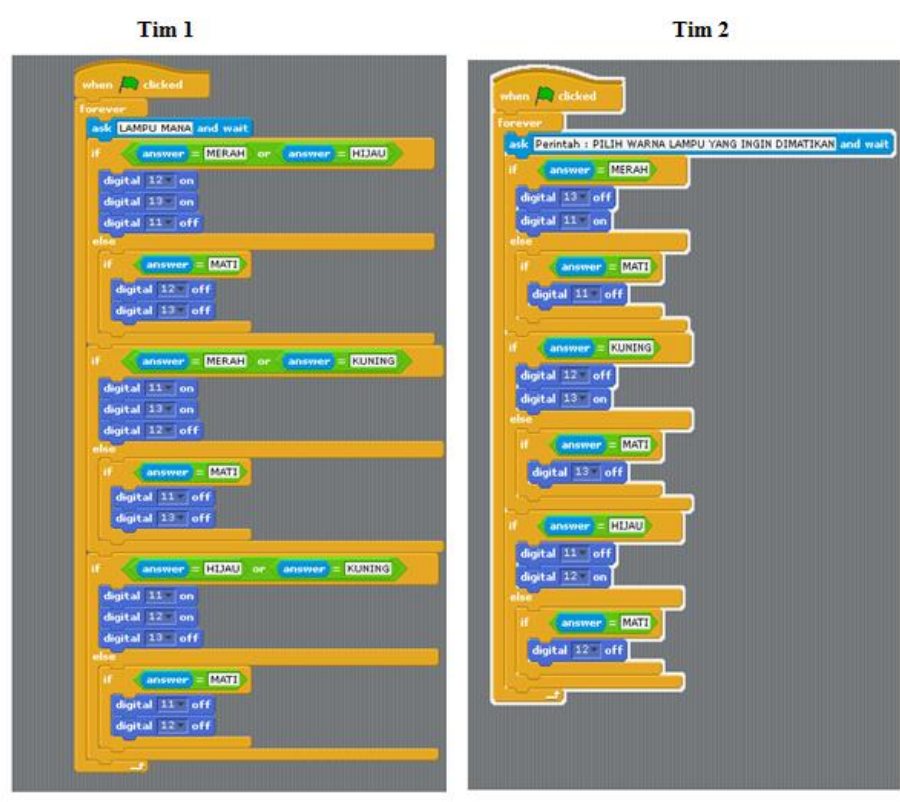

Figure 3. Representation of students' logical thinking ability on the 5th indicator in completing the same project

In the picture above it can be shown the ability of students in representing the same problem but different in representing in the form of block programming, in Team 2 produces a short 
block programming language with a very good average value, while in Team 2 produces a programming language blocks several execution processes to solve problems with the Good category.

Indicator 7 is the ability of Prepare analysis and synthesis of cases. In this ability students are required to be able to make conclusions according to the solutions and analyzes that have been made.

The picture below is the ability of 2 teams to draw conclusions on a case in a project.

$$
\begin{gathered}
\operatorname{lm} 1 \\
\text { KESIMIPULAN }
\end{gathered}
$$

Dari eksperimen yang nanti akan dilakukan kami bisa mengimplementasikan percobaan hubungan Volume dan Suhu pada fenomena Anomali Air ini bisa kami uji kebenarannya dengan bantuan perangkat Arduino dan Mathlab.

$$
\operatorname{Tim} 2
$$

\section{KESIMPULAN}

Pembuatan alat ukur suhu dengan LM35 dengan memanfaatkan piranti Arduino Uno agar mendapatkan pengukuran suhu cairan yang lebih akurat dan mempermudah dalam pengambilan data untuk pengukuran suhu cairan.Dalam pengukuran suhu cairan menggunakan komponen utama IC LM35 sebagai sensor suhu, LM35 merupakan sensor suhu yang akurat dimana tegangan keluarannya berbanding lurus dengan suhu dalam derajat celcius sebesar $10 \mathrm{mV}$ untuk setiap perubahan suhu $1^{\circ} \mathrm{C}$.

Figure 4. Ability to draw conclusions on the 7th indicator of computational logical thinking ability

Gambar 3 di atas menunjukkan kemampuan kedua tim dalam membuat kesimpulan dari suatu kasus. Tim 2 menunjukkan kemampuan yang lebih baik daripada Tim 1. Tim 2 mampu membuat kesimpulan sesuai dengan poin-poin penyelesaian dengan lengkap dengan sesuai tujuan proyek. Tim 1 menunjukkan dalam membuat kesimpulan hanya poinpoin umum saja belum sesuai kasusnya.

\section{Suggestion}

Physics learning media is a learning tool to help students to understand physics concepts more easily. Learning media developed is adapted to the development of current microcontroller technology. Besides that, with the characteristics of physics learning that are abstract and require high reasoning, a media is needed to improve computational logical thinking skills to help solve various physical phenomena that surround it. The results showed that there had been an increase in computational logical thinking skills such as making conclusions, making solutions, making evidences and making hypotheses. \%. It was also showed that there was an increased in compiling analysis and synthesis of several cases by $6,7 \%$.

The resulting value category increases in the very good and good categories. This study shows that the implementation of S4A (Scratch for Arduino) can be applied in learning.

\section{Acknowledgment}

This research was supported by the Muhammadiyah University of Purworejo to facilities. The researcher thanks to all institution that has been supporting this research and to the reviewers.

\section{References}

[1] H. V. Thai and M. A.T.K. Anh, "The 4.0 Industrial Revolution Affecting Higher Education Organizations' Operation In Vietnam," International Journal of Management Technology, vol. 4, no. 2, pp. 1-12, October 2017.

[2] B. E. Penprase, The Fourth Industrial Revolution and Higher Education, N. W. Gleason (ed.), 2018.

[3] S. Nethravathi and R.S.Geetha, "Learning By Doing: Implementing In Microcontroller Course," Journal of Engineering Education Transformations, eISSN 23941707.

[4] Santoso et al," Pembuatan Otomasi Pengaturan Kereta Api, Pengereman, dan Palang Pintu Pada Rel Kereta Api Mainan Berbasis Mikrokontroler.” Jurnal FEMA, Vol 1, No.1. 2013.

[5] Y. J. Mon and Y. S. Kuo, "The Ultrasound Applications Based on Microcontroller Board," Journal of Scientific and Engineering Research, vol 3, No. 3, pp. 211-214, 2016.

[6] Aozon, Bagian-Bagian Arduino dan Kelebihannya, http: //aozon. blogspot.co.id/2014/03/mengapa -harusarduino- beberapa kelebihan. html, 2014.

[7] Chong Li, "Maker-based STEAM education with Scratch tools," World Transactions on Engineering and Technology Education, vol.14, no.1, pp. 151-156, 2016.

[8] S. Arikunto, Prosedur Penelitian. Yogyakarta: Rineka Cipta, 2002.

[9] I.G. Setiawan, "Penerapan Pengajaran Kontekstual Berbasis Masalah untuk Meningkatkan Hasil Belajar biologi Siswa Kelas X2 SMA Laboratorium Singaraja."Jurnal Penelitian dan Pengembangan Pendidikan, vol.1, no. 2, pp. 42-59, 2008. 